\title{
OBITUARIES
}

\section{Dr. W. R. G. Atkins, C.B.E., F.R.S.}

THE death occurred on April 4 of William Ringrose Gelston Atkins at the age of seventy-four. Son of the late Thomas Gelston Atkins, M.D., of Cork, W. R. G. Atkins was born on September 4, 1884. After his schooldays at the Friend's School, Newtown, Waterford, and the Grammar School, Cork, he went to Trinity College, Dublin, where he took two honours degrees in physics and chemistry, and in botany, zoology and geology. He was awarded Senior Moderatorships in Experimental and in Natural Sciences in 1906, and was then successively assistant, during 1906-11, to the late Prof. S. Young, the University professor of chemistry, and during 1911-20, to the late Prof. H. H. Dixon, the University professor of botany, in Trinity College, Dublin. The latter period was broken by the First World War, in which Atkins was an assistant chemist at Woolwich Arsenal in 1915 and a volunteer assistant in the Division for Aeronautical Chemistry of the National Physical Laboratory for the first six months of 1916. As a result of his work at the National Physical Laboratory, he was given a commission as equipment officer in the Royal Flying Corps to organize and direct a laboratory in the Experimental Aircraft Establish ment at the Aboukir Depot in Egypt, reaching the rank of major in the Royal Flying Corps. After the War he went for a short time as indigo research botanist at the Imperial Department of Agriculture in India.

In 1921, Atkins was appointed head of the Department of General Physiology at the Plymouth Labora. tory of the Marine Biological Association, where he remained until his retirement in 1955, apart from the years of the Second World War, when he served successively in the Home Guard, the Royal Army Medical Corps, and the Meteorological Office.

Atkins's research work thus falls into two distinct periods, that at Trinity College, Dublin, and that at Plymouth. During the first period it was mainly physico-chemical, including such subjects as the properties of urine and the osmotic pressures of blood and eggs of birds, and of plant tissues. While in Egypt he was specially concerned with the deteriora. tion of fabrics and the study of lubricants. In 1916, he published a book entitled "Some Recent Researches in Plant Physiology".

On his arrival at Plymouth Atkins thus had a very wide background on which to draw for his new field of research, which was the physical and chemical conditions of sea water as an environment for marine life. During his long period at Plymouth he undertook researches, the results of which are now basic to all modern research on the productivity of the sea and have passed into essential background knowledge. These related chiefly to the seasonal variations in the chemical conditions, especially the nutrient salts, in sea water; and to the penetration of light into the sea and the effects of fine particles in suspension. In the latter field Atkins collaborated with Dr. H. H. Poole, of the Royal Dublin Society. As a side-line, Atkins continued work started in Egypt on the deterioration of fabries, in this instance experimenting on methods of preservation of nets and ropes.
His researches on chemical and physical conditions in the sea brought considerable fame to the Plymouth laboratory.

Atkins was an indefatigable research worker, and a noteworthy feature was the way in which he adapted his methods to many environments. For example. his chemical work on sea water was repeated on freshwaters and soils; and his measurements of light were made on land, in woods and in many parts of the world. For many years he ran a continuous light recorder on the roof of the Plymouth Laboratory. He also gave liberally of his advice in many spheres during the Second World War. The range of subjects on which he published is too wide to include in this brief notice.

Atkins held the degrees of M.A. and Sc.D., and was a Fellow of the Royal Institute of Chemistry and of the Institute of Physies ; in the First World War he was twice mentioned in dispatches and was awarded the O.B.E. (Mil.) in 1919. $\mathrm{He}$ was elected a Follow of the Royal Society in 1925, and in 1928 he received the Boyle Medal of the Royal Dublin Society. In 1951 he was appointed a Commander of the British Empire in the King's Birthday Honours. He was president of Section K (Botany) of the British Association for this year's meeting in York.

In his earlier days at Trinity College Atkins was an athlete, and besides playing hockey and rowing at Trinity College, he was especially noted for his boxing. $\mathrm{He}$ became middle-weight champion of Ireland.

A man of great integrity and kindness, he had very many friends from all parts of the world, to whom he and his wife extended much hospitality at their home at Antony in Cornwall. To Mrs. Atkins, and their married son, all who knew him will extend their sympathy. F. S. Russeri.

\section{Prof. Erik Hägglund}

ErIK HäGgLund died in Stockholm on March 13 at the age of seventy-one. His life was dedicated to the elucidation of the involved reactions in processing wood into cellulose and paper, more particularly the chemistry of the sulphite pulping process, its technology, and the nature of lignin and its secondary derivatives.

Hägglund obtained his scientific education at the University of Stockholm, being fortunate to come under the guidance of an inspiring teacher, Hans von Euler. He received his doctorate in 1914, presenting a thesis on the effect of $p \mathrm{H}$ on alcoholic fermentation. It is one of the very first critical investigations of modern type on hydrogen ion concentration. By the way, Hägglund was the first of von Euler's research students to become the incumbent of a university chair in chemistry among the twelve future professors who emerged from the Euler fold. Hägglund graduated three months before the out. break of the First World War, during which research and chemical technology were given a potent impetus for the sake of national economy and feeding of the people. A few years earlier, the method of fermenting the sugars of waste liquor from the sulphite-pulping 